\author{
Daria Kostecka-Jurczyk \\ ORCID: 0000-0002-8404-7791 \\ Uniwersytet Wrocławski \\ daria.kostecka-jurczyk@uwr.edu.pl
}

\title{
Tying on the mobile apps market and competition rules
}

Date of submission: 3.09 .2019 ; date of acceptance: 15.10.2019

JEL Classification: K21

Keywords: abuse of dominant position, competition rules, mobile services markets

\begin{abstract}
Tying on the mobile apps market and competition rules
\end{abstract}

The dynamic growth of digital markets is conducive to the use of anti-competitive practices by companies in order to maintain or strengthen their market position. One example of such practices is the abuse of the dominant position occupied by Google, including by tying Android with applications available on Google Play. This tying means that Google imposes on the smartphone manufacturers a "set of applications" necessary to be installed, even if they were not interested in pre-installing some of them. The study analyzes the anti-competitive practices that the European Commission accuses Google of in the decision of 18 August 2018. The purpose of the article is to examine whether tying a specific set of applications with the Android system meets the conditions for abuse of Art. 102 TFEU. This requires, first of all, an examination of whether Android is a binding product for applications available in Google Play and, if so, of whether the conditions of abuse in the form of sales binding are met. As a result, it has been shown that on digital markets, where there is dynamic competition, it is difficult to make an unambiguous assessment of anti-competitive behavior and one of the important arguments that may prejudge the abuse is the harm to end users.

\section{Introduction}

The dynamically growing number of applications available on the market has resulted in the very fast growth of the mobile device market (smartphones and tablets market). This market is currently one of the fastest growing segments of the 
telecommunications market. ${ }^{1}$ Competition between smartphone manufacturers is constantly growing and becoming more and more harsh, but is not limited to the problem of mobile devices innovation. Access to app stores is also important. Currently, Google Play dominates the market (on Android) and its main competitor is the App Store (for iPhone users). Google Play is a global store where users can receive all kinds of applications created by Google on Android devices. The other store is a digital iOS application platform owned by Apple (App Store). The main parameters of competition on this market are price, design, operating system and patents. Android currently has a $75.27 \%$ share on the mobile operating system (mOS) market, iOS Apple has 22.74\%, Samsung 0.22, KaiOS 0.75\%, Windows $0.24 \%$ and other vendors have $0.22 \% .{ }^{2}$ For comparison, in 2015 Android had an $82.8 \%$ market share, iOS Apple 13.9\%, Windows Phone 2.6\% and Blackberry $0.3 \%$. The remaining systems occupied $0.4 \%$ of the market share. ${ }^{3}$ Despite the decline in market share, Android is still the dominant operating system. Due to the fact that app stores are provided by the same company that also provides mobile operating system (mOS) services, mOS and app store markets are clearly interdependent. This selection of app stores is associated with the offer available with mOS. It leads to the creation of vertical links between mOS and available applications and is not without significance for the selection of a specific mOS by smartphone manufacturers and their users. As a result, it can motivate anti-competitive behavior, as exemplified by Google (European Commission MEMO 15/4782).

\section{Theoretical framework of the research}

The European Commission has recognized that Google contracts with smartphone and tablet manufacturers using the Android operating system for mobile devices (Android OS) contain clauses that enforce pre-installation of the Google search application and the Chrome web browser (European Commission Press Release IP/18/4581). On 18 July 2018, the European Commission issued a decision imposing a fine of 4.34 billion Euro on Google (Case COMP/AT.40099). It found that Google adversely affects competition on the mobile browser market by forcing smartphone manufacturers who want to pre-install the Android Google app store on their devices to pre-install, among others, Google Chrome and Google Search (and set the latter as the default). According to the Commission, these are

1 The market development of today's smartphones began in 2006 when Blackberry entered the market, then iPhone joined in 2007 and Samsung in 2008. Currently, there are many smartphone manufacturers, the vast majority of which entered the market after 2007.

2 Statcounter, http://gs.statcounter.com/os-market-share/mobile/worldwide(accessed: 17.06.2019).

${ }^{3}$ H. Ngoc Anh, Smartphone Industry: The New Era of Competition and Strategy, https://www. theseus.fi/bitstream/handle/10024/119385/FinalthesisHNA.pdf?sequence=1\&isAllowed=y (accessed: 17.06.2019). 
exclusionary practices. In the Commission's opinion Google has a market share of more than $90 \%$ on the Android app store market and excludes from the market the appropriate app stores such as the App Store belonging to Apple.

According to the Commission, Google also has a market share of more than $90 \%$ on the market of general search engines and the application store for the Android operating system (Case AT.39740). The problem was that the Google Play store and the Google Search app are very much sought after by smartphone manufacturers and Google forced them to buy a whole set of applications together. These practices constituted a restriction of competition on the market of unlicensed mobile operating systems and search engine software by forcing smartphone manufacturers who wanted to pre-install certain applications belonging to Google to pre-install other Google applications. The Commission also accused Google of protecting its dominant position in the search engine market by granting financial benefits to smartphone manufacturers, provided that they pre-installed Google Search as the only search tool in their devices.

According to the Commission, such contract clauses are exclusionary practices (Kohutek, 2012, 389-420). They consist in the fact that if a smartphone manufacturer wants to pre-install one of the Google applications on its device, it must install all applications contained in Google Mobile Services (this is the so-called all or nothing requirement). Such a clause is often justified because it makes Android devices more attractive compared to, for example, an Apple iPhone. It is therefore necessary to ask the question about the importance of such practices from the competition rules point of view. If they are classified as sales tying, they will constitute abuse of Art. 102 TFEU (Treaty on the Functioning of the European Union).

\section{Research methodology}

This problem has not been studied so far. It is based on the European Commission's decision of 18 July 2018 (COMP/AT.40099). There are publications in the literature on the general issue of product tying by dominant companies (Edelmann, 2015; Miąsik, 2009; Swora, 2005; Targański, 2005), but few publications concern abuse of a dominant position in digital markets. This study is a contribution to the discussion on the use of new technologies to unlawfully strengthen or maintain a dominant position by companies. The article was based on literature research, synthesis of existing regulations, case law of EU courts and decisions of the European Commission.

\section{Tying in the light of competition law}

Tying is an agreement where the seller of one product makes his sales conditional on the purchase of other often complementary products. In binding contracts, the 
entrepreneur sells not only the product/service that the customer wants to buy, but obliges him to buy an additional item or service, regardless of whether the customer wants it or not (Targański, 2005, 380).

Tying usually takes one of three forms: contractual, technological and packet (Wish, 2009, 679). Contractual tying occurs when the company bundles the purchase of a second (related) product with the purchase of the first product. Therefore, the purchase of the main product is conditional upon the purchase of another (related product/service). Technological tying occurs when the entrepreneur combines different products into an integrated product that can not be decrypted or designs his product in such a way that it is incompatible with a competitive related product.

In turn, in package sales contracts, an additional product is included in the main product. This involves the sale of a package of products not related in substance, or customarily at a price that is more attractive than the price of these products, and especially the price of the main product sold separately by the dominant company. The essence of this form of abuse is forcing clients to take unfavorable actions for them that they would not take if the market was competitive. In the case of pure bundled sales, products are only sold together in fixed proportions. In turn, in mixed bundled sales, also known as multi-product rebates, products or services can be purchased separately, with the sum of their prices being higher, compared to those offered in the package (Communication from the Commission, 2009). This practice is of an exploitative nature, but it can also be exclusionary when it leads to the elimination of competitors from the market.

Both in tying and bundling agreements, which are in violation of Art. 102 TFEU, customers have no choice but to buy both products or neither of them. It should be emphasized that the agreement containing the condition to purchase an additional (related) product is legal if there is no obligation to purchase an additional product. Thus, the abuse occurs when there is a compulsion for a contractor to purchase a specific product (service) that he would not have bought if he could choose (Banasiński, 2018, 150). Tying and bundling are common practices that aim to supply consumers with better products or offer them for a more attractive price. However, an undertaking in a dominant position on the market for one or more of the tying or bundling products (called primary product market) carrying out such sales may harm consumers by foreclosing the market for other products which are offered in tying or bundling sale (called the related product market) and indirectly the primary product market (Commission Guidelines, 49).

Tying in the context of Art. 102 TFEU was analyzed in detail in Case C-333/94, Tetra Pack II. In this case, the Court of Justice of The European Union (CJEU) claims that when a dominant trader sells one product (product binding) depending on the acquisition of the other product (related product), it may result in abuse, even if such sales are in line with commercial practice and even if the two products are closely related, unless the natural relationship between them can be objectively 
justified. Tetra Pack argued that both products (carton filling device and cartons for dairy products) are an integrated service. The CJEU dismissed this argument and ruled that it would be reasonable to consider the production of equipment and cartons as creating a natural relationship and thus treat them as integrated services only if there were no other independent producers specializing in the production of non-aseptic packaging or if it was not possible for other entrepreneurs to start production of non-aseptic packaging for reasons related to intellectual property rights.

This was confirmed in the Hilti judgment against the Commission (Case T-30/89, Hilti AGv Commission) in which the CJEU ruled that Hilti had abused its dominant position by demanding from the end recipients or distributors of its patented strips to purchase nails and thereby tying the cartridge strip and nails. Hilti argued that the binding agreement was necessary for the protection of users which the CJEU did not take into account. The CJEU stated that this did not justify tying.

The related sales were conducted by Microsoft in the same way - it is about binding Windows Media Player and the operating system, which was considered an abuse of Art. 102 TFEU and an earlier operating system and Internet Explorer (Case COMP/C-3/39.530, Microsoft). The court ruled that Windows Media Player and the operating system were two separate products based, among others, on their various functionalities (Case T-201/04, Microsoft v Commission; Miąsik, 2008, 88).

When analyzing Google's behavior as an abuse of a dominant position, it should be emphasized that the notion of abuse is an objective concept (Molski, 2007, 140-148). It refers to the behavior of an entrepreneur in a dominant position that may affect the structure of the market, where competition is already weakened due to the presence of such an entrepreneur, and behavior that creates an obstacle to maintaining the existing level of competition or its development on the market by using measures different from those used in conditions of normal competition between goods or services based on the services of business entities.

The behavior of an undertaking in a dominant position can therefore be considered an abuse within the meaning of Art. 102 TFEU even without any fault. Consequently, the fact that an undertaking in a dominant position did not pursue any anti-competitive objective does not affect the legal classification of the facts. In this context, demonstrating the purpose of the contested activities of the undertaking in a dominant position may give rise to the finding that abuse of a dominant position has occurred, but that is not a condition (Case T-301/04, Clearstream Banking AG \& Clearstream International SAv Commission).

In the case of Google, one should pay attention to the fact that almost all smartphone manufacturers pre-installed applications of one brand. The smartphone market is particularly competitive. Due to the fact that applications are additional software for use on the device, they must be written to be compatible with specific mOS devices. The application written for Android will not work on an iPhone powered by iOS Apple. For this reason, Android is a binding product and is used to link this system to the Google Play store. 


\section{Android as a tying product}

Android is an open-source operating system (open-source OS). It is primarily designed for smartphones and tablets and has been maintained by Google since 2005 (Callaham, 2008). Android is distributed through open-source licenses, which allows anyone to obtain the code and modify or develop free apps on it. By offering Android OS and applications free of charge to smartphone manufacturers, Google maximizes the number of users of its applications and therefore advertising revenue. Google applications are not open(-source), but Google provides some of them to mobile device manufacturers for Android OS free of charge. This set of Google services on mobile devices includes applications such as the Google Play store (Android-based store), Google Search, Google Chrome and Google Maps. Manufacturers of mobile devices can not choose which Google applications they will install. They must install applications that comply with a contract previously agreed with Google (mobile application distribution agreement - MADA) (Field, 2014). A smartphone manufacturer may acquire an OS license and not pre-install any Google application. It can also change the Android code and customize it. However, if it wants to pre-install one application included in the set - it must pre-install all the ones imposed by Google. The European Commission is opposed to applying the "all or nothing" requirement, recognizing that it is a binding sale that violates competition law. The Commission considered that the "all or nothing" clause used by Google distorts competition in the market for certain applications, such as searching and browsing websites on mobile telephony. The Commission is particularly concerned that Google protects its dominant position in the online search market by ensuring that Google Search is pre-installed on most Android phones and Google Search is the default search engine that closes the market access to competitive search engines (Edelmann, 2015, 389-390).

It is a tying sale practice, which may result in the exclusion of competitors from the market (Kohutek, 2008, 389-420). Google's binding also blocks competition from alternative mobile ecosystems. Namely, it limits the producers of smartphones and other mobile devices to use Android forks. ${ }^{4}$ For example, Amazon Kindle Fire is customizable for Android and is able to launch Google Maps, most or all other Google applications, and most or all applications in the Google Play store. However, Fire is not compatible with Google's limitations that are contained in contracts with mobile device manufacturers and therefore cannot be pre-installed. However, it is difficult to install Google apps without the Google Play store. To pre-install the main Google applications such as the Play store and Google Search on mobile devices, vendors must commit that they will not develop or sell any devices operating on "forks." According to the Commission,

${ }^{4}$ Forks are alternative versions of Android that cannot be installed unless approved by Google. 
this limited the possibilities of selling forks. In this way, Google prevented the expansion of other application developers and also, in particular, the development of innovations in mobile services. Therefore, the question is whether these practices can actually be classified as binding and assessed in the context of exclusion practices violating Art. 102 TFEU.

\section{Google's tying apps antitrust analysis}

The "all or nothing" requirement, by forcing mobile device manufacturers to pre-install all applications in Google mobile services (GMS) sets does not deprive smartphone manufacturers of the source of supply of related products in the GMS set, nor does it deprive other market producers of applications (Case Tetra Pack II, 137). In assessing the extent to which integrated design could exclude the possibility of competitors, courts should also consider how easy or difficult it is for consumers to use independent offers together with an integrated product. Samsung, a market leader in smartphones, pre-installed on Google smartphone Galaxy S6 with GMS along with other applications that perform the same functions as those in the GMS sets. Google in the complaint against the Commission's decision (Case T-604/2018) argues that the Commission failed to take into account in the contested decision that these pre-installation conditions are objectively justified because Google could provide free operation of the Android platform (Action brought on 9 October 2018 - Google and Alphabet $v$ Commission, Case T-604/2018).

In the literature one can find the view that competition is excluded because many applications are duplicating and therefore misleading for users. Users who have pre-installed applications on their computers were less likely to download alternative applications due to their reluctance to learn about new technologies (Edelmann, 2015, 391). In reality, however, it is difficult to prove a negative impact on competition. Application developers can use the GMS set as an integrated part of the Android operating system and their applications can work with the applications in the set. One of many solutions is Google Maps. Developers can significantly improve the functionality of their applications, including online map links that are installed on users' phones. This is especially important in applications that contain information about local services or applications that direct users to a specific place. Instead of copying the address or place name from the application's user and then pasting it into the map application, the developer may include several links with codes which, when the user clicks on the application, redirects the user to the application with the maps on the given device. Application developers can build applications that will be compatible with basic Google applications and create more valuable applications. This allows Android as an open system to compete with a closed system like the Apple operating system and reduce entry barriers for application developers. This is beneficial for both users 
and developers. In addition, Google has prepared a version of its own applications (Google Maps, Google Chrome, Google Search and YouTube) available for download from the application store to other operating systems.

Assessing the anti-competitive effects of Google's requirement - all or nothing - however, it should be noted that smartphone makers were not forced to sign a mobile application distribution agreement or install a Google application suite. Both the Amazon (Kindle Fire) tablet and the Nokia X smartphone worked on the Android system, but operated without a pre-installed Google set. The Kindle Fire app store is from Amazon and is based on the Bing search engine. Smartphone manufacturers have not denied that they had the option of choosing which applications were pre-installed on their devices and there is no anti-competitive damage if the Android operating system is available separately from the Google Application Kit. It is also worth mentioning that barriers to the mOS market are low because Google grants open licenses for Android. Everyone can download the Android source code and create their own mobile operating system. Taking the above into consideration, it cannot be unambiguously confirmed that Google's practices constituted an abuse of a dominant position consisting in tying Android to applications available on Google Play. When analyzing the anti-competitive behavior of Google, it is first of all necessary to check whether the conditions for the abuse of tying were met. These include:

1. Making the conclusion of the contract dependent on the fulfillment or acceptance of another service (e.g., the contractor has no choice).

2. Tying products or services.

3. Lack of a relationship between the tying product and tied products produced by dominant undertaking.

In practice, it is enough for the trader to face the other side before having to accept non-negotiable conditions (Case SOKiK of 17.10.2006, XVII AmA 34/05). The dependence on the conclusion of the contract is examined, based on the "counterparty's rational behavior" test. It is assessed on the basis of the "hypothetical assumption of competition on the market." Abuse of a dominant position occurs when the dominant side is able to require the commitment from the business partner (Miąsik, 2009, 659).

In the case of the first condition, it should be pointed out that, first of all, basically MADA allows device manufacturers to install third-party applications in addition to specific Google applications. However, many applications are duplicated, confusing users, and have limited equipment resources. You can use Android devices without Google applications. However, without any Google applications, such devices appear to be unattractive to smartphone users. Without the Play store, users will have problems downloading applications from Google or others. Although Android is an open system, Google has used its market power by restricting access to the Play store. Similarly for the second key product - the YouTube app. Selling a smartphone to consumers in Europe and the US without high quality access to 
YouTube seems impractical. In addition, users can search for Android and Google applications in any combination: some may want Android with third-party applications; others only want some Google applications. Each application has a separate name, installation package and icon. There is no logical or technical reason why installing one application requires the installation of others.

As for the second condition - it should be pointed out that combining applications together can strengthen Google's dominant position because a manufacturer that does not find a replacement for even one Google application has no alternative and installs all the applications in accordance with the mobile application distribution agreement. Some manufacturers may want to offer devices that use Bing search, Duckduck, Mapquest or Yahoo Maps by default, but only Google Play store allows the manufacturer to offer comprehensive applications. Then it would not be possible to pre-install YouTube, which would be unattractive for many consumers. To provide customers with access to Google Play and YouTube, the smartphone manufacturer must accept Google search, maps, network location provider and others, even if the manufacturer prefers offering competitive services. It seems, therefore, that device manufacturers must install the full Google suite. They cannot install even alternative search capabilities or maps because this would require previous Google key applications.

Google's practices should also be considered in the context of harm to consumers. In the case at hand, this damage is due to restrictions on the Google Play app store. Without Play, the device does not easily install Google applications you requested or other applications available only or most easily through Google Play. Users are not interested in Android devices that do not have Play. By restricting YouTube features on Windows Phone devices, Google is particularly weakening this platform. It is the strongest competitor for Android on the operating system market to be installed on third-party hardware. Without a fully functional YouTube application, a Windows Phone becomes less attractive to consumers. If Google stops the functioning of competing mobile systems, such as Windows Phone, the user of a Windows Phone receives worse functionality (Windows Phone cannot offer a fully functional YouTube application without metadata that is stored by Google). In this case, one can talk about harm to the consumer. An important question to ask is regarding the objective justification of Google's practices. One cannot in any way justify the requirement from all producers to install a Google offer. Device manufacturers can opt out of the entire suite of Google applications and services.

However, a smartphone without these applications will be less useful to the consumer. Therefore, it is not profitable from the point of view of producers of mobile devices. In addition, if the manufacturer resigns from the entire set of Google services, users will not have access to Play to obtain the desired applications. Google has also failed to provide any reason why Windows Phone applications should not be granted full access to YouTube. According to the Commission, Google's behavior was harmful to users because it prevented access to other devices 
and innovations of mobile devices based on alternative Android versions (European Commission, MEMO 15/4782).

\section{Conclusions}

The analysis of Google tying based on the premises contained in the guidelines of the European Commission indicates that they can be qualified as exclusionary practices. However, it should be emphasized that in the markets of new technologies where dynamic competition is present, it is difficult not only to assess anti-competitive effects, but also to determine whether the entrepreneur actually has a dominant position. By imposing a range of applications that must be installed on mobile devices (and those which are not), Google shapes popular services. Google tries to justify the inability to provide free operation of the Android platform in the event that mobile device manufacturers would like to pre-install only selected applications. Some of them do not generate income. This is an argument that may determine whether pre-installation conditions are objectively justified because Google could provide free-of-charge Android platform functionality.

In the decision of 18 August 2018, the Commission forced Google to propose remedies. Google has promised that both Google's own services and competitors' offers will be visible in the search results. However, concerns can be expressed as to whether the proposed changes will solve the problems. In this case, the natural remedy seems to be opening all links, allowing competitors to completely replace Google's offers (if users choose it) rather than to present to consumers parallel offers from both Google and competitors. The Commission's decision was appealed to the Court and we have to wait for the judgment and arguments supporting the Commission's opinion or otherwise. Perhaps this ruling will move the boundaries of Art. 102 TFEU outside its current scope.

\section{References}

\section{Literature}

Banasiński, C. (ed.) (2018). Polskie prawo antymonopolowe. Zarys wykładu. Warszawa: Wolters Kluwer.

Edelmann, B. (2015). Does Google leverage market power through tying and bundling? Journal of Competition Law \& Economics, 11(2), 389-390.

Field, I. (3.05.2014). A look at Google's not-always-secret contracts with Android phone makers. Retrieved May 25, 2010 from https://www.vox.com/2014/5/3/11626422/a-look-at-googles-not-always-secret-contracts-with-android-phone.

Kohutek, K. (2008). Zakaz praktyk ograniczających konkurencję. In K. Kohutek, M. Sieradzka, Ustawa o ochronie konkurencji i konsumentów (334-444). Warszawa: Lex-Wolters Kluwer.

Kohutek, K. (2012). Praktyki wykluczajace przedsiębiorstw dominujacych. Warszawa: Lex-Wolters Kluwer.

Ekonomia - Wroclaw Economic Review 25/3 (2019)

(C) for this edition by CNS 
Miąsik, D. (2008). Sprzedaż wiązana systemu operacyjnego z oprogramowaniem użytkowym Windows Media Player. In D. Miąsik, T. Skoczny, M. Surdek (eds.), Sprawa Microsoft. Studium przypadku: prawo konkurencji na rynkach nowych technologii (88). Warszawa: Wydawnictwo Naukowe Wydziału Zarządzania Uniwersytetu Warszawskiego.

Miąsik, D. (2009). Komentarz do art. 9 OKiKU. In T. Skoczny (ed.), Ustawa o ochronie konkurencji i konsumentów (659). Warszawa: C.H. Beck.

Molski, R. (2007). Prawo antymonopolowe w obliczu globalizacji. Kierunki rozwoju. Szczecin-Bydgoszcz: Branta.

Swora, M. (2005). Zakaz stosowania transakcji wiązanych przez podmioty dominujące na rynku z perspektywy europejskiego, amerykańskiego i polskiego prawa antymonopolowego. Przegląd Prawa Europejskiego 1, 45-66.

Targański, B. (2005). Praktyka wiązania świadczeń jako forma nadużycia pozycji dominującej w świetle decyzji Prezesa Urzędu Ochrony Konkurencji i Konsumentów. Przegląd Ustawodawstwa Gospodarczego 8, 22-29.

Wish, R. (2009). Competition Law. Sixth ed. Oxford: Oxford University Press.

\section{Legal acts}

Treaty on the Functioning of the European Union, OJ C 115.

\section{Guidelines of the EU Commission}

Commision Guidelines: Communication from the Commission - Guidance on the Commission's enforcement priorities in applying Article 82 of the EC Treaty to abusive exclusionary conduct by dominant undertakings, OJ UE 2009, C 45/7.

\section{Judgments of the Court of the First Instance}

Case T-604/2018, Google and Alphabet v Commission. Retrieved May 30, 2019 from: http://curia. europa.eu/juris/document/document.jsf?text $=\&$ docid $=208802 \&$ pageIndex $=0 \&$ doclang $=P L \&$ mode $=$ req\&dir $=\& o c c=$ first\&part $=1 \& \operatorname{cid}=5882743$.

Judgment of the CFI T-30/89, Hilti AG v Commission, ECR 1991, II-1439.

Judgment of the CFI T-83/91, Tetra Pack International SA v Commission, ECR 1994, II-755.

Judgment of the CFI T-201/04, Microsoft v Commission, ECR 2007, II-3601.

Judgment of the CFI T-301/04, Clearstream Banking AG \& Clearstream International SAv Commission, ECR 2009, II-3155.

Judgment of the CJEU C-333/94, Tetra Pack v Commission, ECR 1996, I-5951.

\section{Judgments of Polish courts}

Judgment of SOKiK of 17.10.2006, XVII AmA 34/05, non-published.

\section{Decisions of the European Commission}

Commission Decision of 16.12.2009 in case COMP/C-3/39.530 — Microsoft (Tying). Retrieved May, 20, 2019 from http://ec.europa.eu/competition/antitrust/cases/dec_docs/39530/39530_2671_3. pdf.

Commission Decision of 27.06.2017 in case AT.39740 — Google Search (Shopping), OJ UE 2018, C 9.

Commission Decision of 18.07.2018 in case COMP/AT.40099 — Google Android, non-published.

Ekonomia - Wroclaw Economic Review 25/3 (2019)

(C) for this edition by CNS 


\section{Others}

Callaham, J. (2018). Google made its best acquisition 13 years ago: Can you guess what it was?. Retrieved May 30, 2019 from https://www.androidauthority.com/google-android-acquisition-884194/.

European Commission MEMO 15/4782.

European Commission Press Release IP/18/4581. Retrieved May 27, 2019 from http://europa.eu/rapid/ press-release_IP-18-4581_en.htm.

Ngoc Anh, H. Smartphone Industry: The New Era of Competition and Strategy. Retrieved June 17, 2019 from https://www.theseus.fi/bitstream/handle/10024/119385/FinalthesisHNA.pdf?sequence $=1 \&$ isAllowed $=\mathrm{y}$.

Statcounter. Retrieved June 6, 2019 from http://gs.statcounter.com/os-market-share/mobile/worldwide. 